\section{Improved Heat Pulse Velocity Meter $^{1}$}

\section{GERALD F. GIFFORD AND \\ GARY D. FRODSHAM}

Assistant Professor, Range Science Department, and Research Engineer Electro-Dynamics Laboratory, Utah State University, Logan.

\section{Highlight}

A heat pulse velocity meter useful for studying sap movement is described. The instrument is updated electronically and is slightly more compact than previous units.

Study of transpiration from grass, shrub, and tree species has long been of interest to wildland hydrologists. Though many techniques are available for studying transpiration, few are rapid or measure individual plants.

In recent years several researchers have utilized the heat pulse technique to study sap movement. Swanson (1967b) has provided a brief summary of the heat pulse method, and the following is taken from his paper:

"In any pulse velocity measuring technique, a quantity of heat is injected into the stem of a plant, and its rate of travel to some point downstream, indicated as a rise in temperature, is detected by thermocouples or thermistors. Huber (1932) empirically related the first onset of heat at the point to sap velocity. Marshall (1958) derived the theoretical relation between heat rise with time at the point and sap movement in conifers. Marshall's relation is exact at any sap speed, but because of ambient temperature changes within a tree stem in the field, it yields useful values only at relatively high flows-those causing heat pulse velocities greater than 10-15 $\mathrm{cm} / \mathrm{hr}$. Such sap velocities are uncommon in Rocky Mountain conifers. A better technique for these lower velocities requires two temperature measurement points, one upstream and one downstream from the heat insertion point (Huber and Schmidt, 1937; Swanson, 1962).

According to Marshall (1958), heat pulse velocity is a weighted average of the velocity of moving sap and station-

\footnotetext{
${ }^{1}$ Development of this instrument was supported by the Ecology Center, Utah State University, under Project
} 28. Received December 1, 1970.

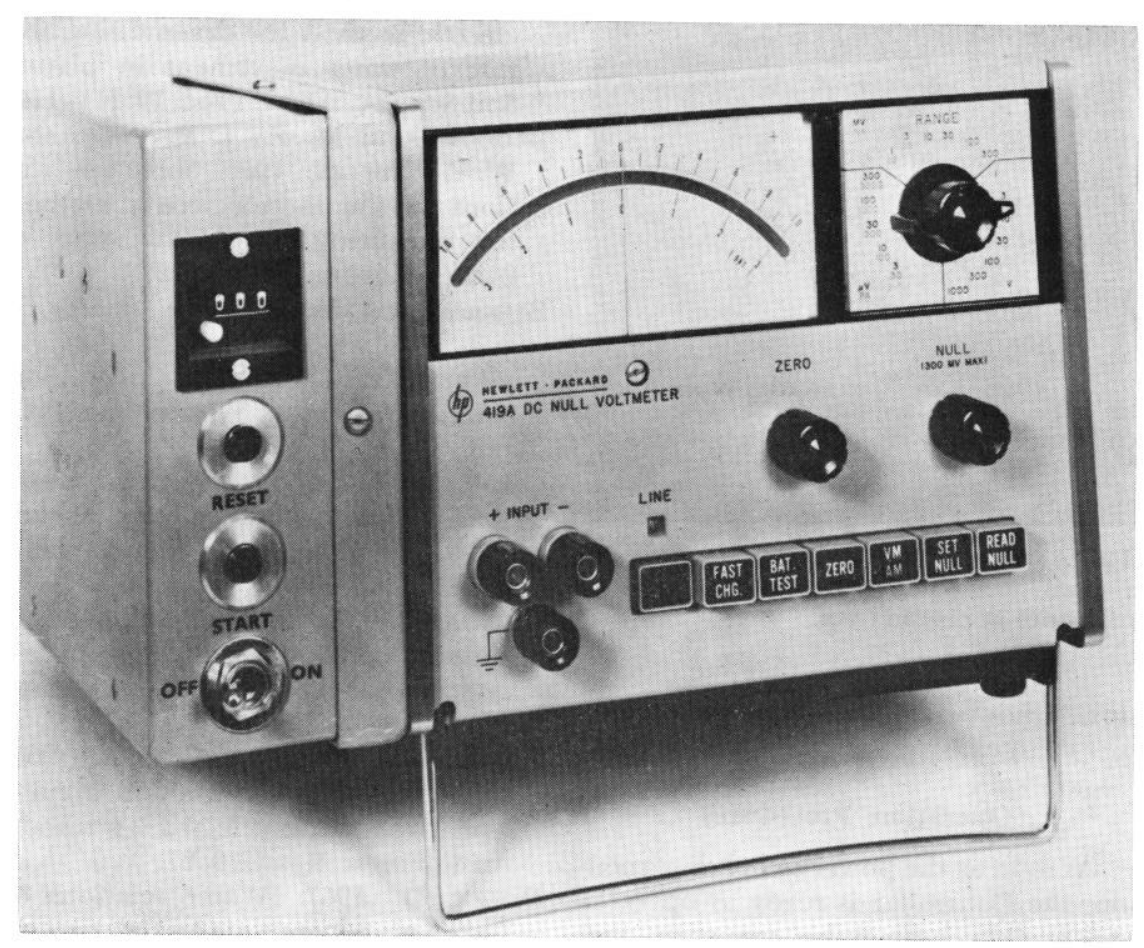

FIG. 1. Microvoltmeter with heat pulse and timing circuits in box attached to side.

ary wood. At low sap velocities, the effect of the wood predominates, and heat pulse velocity is an underestimate of real sap velocity. At high sap velocities, the effect of the wood is less and heat pulse velocity is very close to real sap velocity. The weighting effect of the wood is a function of the area occupied by sap streams. This area is unknown and not necessarily constant. Therefore, true sap velocity is unknown; heat pulse velocity indicates whether or not there is sap flow, and to some degree its relative, but not true, magnitude."

Field and laboratory tests for verification of theory were undertaken by Skau and Swanson (1963), Decker and Skau (1964), and Ladefaged (1960). Measurement of sap movement by this procedure, or slight modifications thereof, have been undertaken on a variety of plants; Bloodworth et al. $(1955,1956,1960)$ studied sap flow in cotton, Marshall (1958) and Decker and Skau (1964) in conifers and junipers, Gale and Poljakoff-Mayber (1964) in pine and orange trees, Wendt et al. $(1965,1967)$ in corn, sorghum, oats, and mesquite, Swanson (1967) in lodgepole pine and engelmann spruce, Doley (1967) and Doley and Grieve (1967) in eucalyptus, Hart et al., (1969) in aspen, and Gifford (1968) in big sagebrush.
Swanson (1967a) outlined several important changes in the basic instrumentation which he developed earlier. The purpose of this paper is to describe recent changes which update the instrument electronically as well as present a somewhat more compact unit. The reader is referred to Swanson (1967a, Appendices) for discussion of temperature measuring, heat sources, connections and spacing of probes, and drilling.

\section{The Instrument}

A Hewlett-Packard2 419 A DC Null Voltmeter is the basic unit used to determine, following heat input, when temperature probes are again at an equal temperature (Figs. 1 and 2). The voltmeter can detect a difference of \pm 0.1 microvolt and can operate 30 hours per recharge.

The model SK-1 Heat Pulse Controller and Clock Display ${ }^{3}$ is designed to mount on the side of the voltmeter. The self-contained portable controller provides approximately $6.25 \mathrm{v}$ at the output terminals for precisely 2 seconds. The Controller may be operated

${ }^{2}$ Hewlett-Packard, 1501 Page Mill Road, Palo Alto, California 94304.

${ }^{3}$ Instruction manual may be obtained by writing the senior author. 


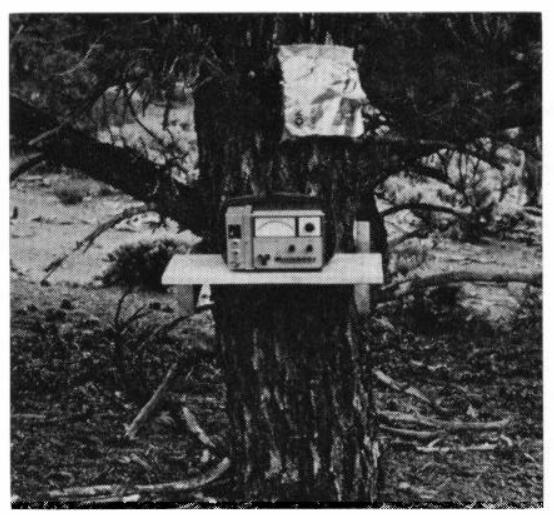

FIG. 2. Microvoltmeter and Heat Pulse Controller set up for measuring sap velocities in pinyon trees.

for 30 hours ( 1 pulse every 5 minutes) per charge.

\section{Operation Procedures}

As soon as the power switch is turned on, the Controller is ready to operate. To start a heat pulse sequence, the start button is depressed and released. A red light indicates that the heater voltage has been applied to the output terminals. At the end of a 2-second heat pulse, the 1-second counter displays the number of seconds until the reset button is depressed.

During cold weather (below freezing), operation of the unit is facilitated by addition of an external heat source (small hand warmers, etc).

\section{Practical Applications}

The instrument can be used to study water movement in plants, plant response to herbicide applications, or for studying influence of insects, disease, or grazing on physiology of wildland plants.

\section{Literature Cited}

Bloodworth, M. E., J. B. Page, and W. R. Cowley. 1955. A thermo- electric method for determining the rate of water movement in plants. Soil Sci. Soc. Amer. Proc. 19:411-414. Bloodworth, M. E., J. B. Page, and W. R. Cowley. 1956. Some applications of the thermoelectric method for measuring water flow rate in plants. Agron. J. 48:222-228.

BLoodworth, M. E. 1960. Effect of soil temperature water use by plants. Trans. 7th Int. Congr. Soil Sci. Soc. (Madison, Wisconsin): 153163.

Closs, R. L. 1958. The heat pulse method for measuring rate of sap flow in a plant stem. New Zealand J. Sci. 1:281-288.

Decker, J. P., and C. M. Skau. 1964. Simultaneous studies of transpiration rate and sap velocity in trees. Plant Physiol. 39(2):213-215.

Doley, D., AND B. J. Grieve. 1966. Measurement of sap flow in a eucalypt by thermo-electric methods. Aust. Forest Res. 2:3-27.

Doley, D. 1967. Water relations of Eucalyptus marginata under natural conditions. J. Ecol. 55:597-614.

Gale, J., and A. Poljakoff-Mayber. 1964. Effect of soil moisture stress on the correlation between heat pulse velocity and transpiration. Plant and Cell Physiol. 5:447-455.

GIFFord, G. F. 1968. Apparent sap velocities in big sagebrush as related to nearby environment. J. Range Manage. 21:266-268.

Hart, G., J. D. Schultz, and G. B. Coltharp. 1969. Controlling transpiration in aspen with phenylmercuric acetate. Water Resour. Res. 5: 407-412.

Huber, B. 1932. Beobachtung und Messung pflanzlicher Saftstrome. Ber. deutsch. Bot. Ges. 50:89-109.

Huber, B., and E. Schmidt. 1937. A compensation method for the thermoelectric measurement of slow sap movements. Transl. TT64-16015, Office Tec. Services, Washington, D. C.
LAdEFoged, K. 1960. A method for measuring the water consumption of larger intact trees. Plant Physiol. 13:648-658.

Marshall, D. C. 1958. Measurement of sap flow in conifers by heat transport. Plant Physiol. 33:385-396.

Skau, C. M., and R. H. Swanson. 1963. An improved heat pulse velocity meter as an indicator of sap speed and transpiration. J. Geophys. Res. 68(16):4743-4749.

Swanson, R. H. 1962. An instrument for detecting sap movement in woody plants. U. S. Forest Service, Rocky Mt. Forest \& Range Expt. Sta., Sta. Paper 68. $16 \mathrm{p}$.

Swanson, R. H. 1967a. Seasonal course of transpiration of lodgepole pine and engelmann spruce. Also, Appendixes to above paper. In Proc. Intern. Symp. on Forest Hydrology, Penn. State Univ., Aug. 29-Sept. 10, 1965:417-432.

Swanson, R. H. 1967b. Improving tree transpiration estimates based on heat pulse velocity measurements. In 14 th Intern. Forestry Research Organization, Munich, Germany, Sept. 4-9: 252-263.

Wendt, C. W., C. R. Brooks, and J. R. Runkles. 1965. Use of thermoelectric method to measure relative sap flow in monocotyledons. Agron. J. 57:637-638.

Wendt, C. W., J. R. Runkles, and R. H. HaAs. 1967. The measurement of water loss by mesquite (Prosopis glandulosa var. glandulosa Torr.) using the thermoelectric method. Soil Sci. Soc. Amer. Proc. 31(2):161-164.

\section{CLYDE ROBIN}

NATIVE SEEDS

Castro Valley, California 94546
ILLUSTRATED FUNDAMENTALS OF TREE IDENTIFICATION (applicable to all plants) by Ralph $\mathrm{R}$. Wilson, retired forestry professor. $\$ 1.75$ each, five or more copies $\$ 1.60$ each, postpaid to one address. Write for prices on other quantities. Ralph R. Wilson, 632 South Tenth, Pocatello, Idaho 83201 .
1972 ANNUAL MEETING
25th Anniversary
Washington, D.C.
February 5-11, 1972

The tentative program and schedule of events is in this issue, beginning on page 478. See October and December issues of Rangeman's News for additional information. 